\title{
PENGARUH PENDIDIKAN, PELATIHAN, DAN PENGALAMAN MENGAJAR GURU TERHADAP PROFESIONALISME GURU DI SEKOLAH DASAR ( SD ) NEGERI 050662 PERDAMAIAN KECAMATAN STABAT KABUPATEN LANGKAT
}

\author{
Asyhariah \\ Universitas Islam Sumatera Utara \\ asyhariah@gmail.com
}

\begin{abstract}
The formulation in this research is how the influence of education, training and experience teaching teachers to the professionalism of teachers in elementary School (SD) Negeri 050662 Peace District of Stabat District, Langkat, and the purpose of this research is to Know and analyze the influence of education, training and experience teaching teachers to the professionalism of teachers in elementary School (SD) Negeri 050662 District Peace Stabat District Langkat. This research is a quantitative descriptive study. Data collection techniques are conducted through interviews, questionaire questions and documentation studies. Sample in this study as many as 30 teachers in elementary School (SD) Negeri 050662 District Peace Stabat District Langkat. Variables are measured at Likert scale. Hypothesis testing using multiple linear regression analyses through $F$-test and T-Test. The results of the test in unison showed that the education, training and teaching experience have significant effect on the professionalism of primary school teachers (SD) of the 050662 District peace Stabat with the value of coefficient of determination of 0.554 or $55.4 \%$. In partial, education has a positive and significant effect on the professionalism of elementary school teachers $(S D)$ of state 050662 peace of Stabat subdistrict with a regression coefficient value of 0330 or $33.0 \%$. The training has a positive and significant effect on the professionalism of primary school teacher (SD) Negeri 050662 District Peace Stabat with a regression coefficient value of 0355 or $35.5 \%$. The teaching experience has a positive and significant effect on the professionalism of primary school teacher (SD) Negeri 050662 District Peace Stabat with a regression coefficient value of 0365 or $36.5 \%$. The highest value of a regression coefficient is a teaching experience of 0365 or $36.5 \%$.
\end{abstract}

Keyword : Education, Training And Experience Of Teaching, Professionalism

\begin{abstract}
ABSTRAK : Rumusan pada penelitian ini adalah bagaimana pengaruh pendidikan, pelatihan dan pengalaman mengajar guru terhadap profesionalisme guru di Sekolah Dasar ( SD ) Negeri 050662 Perdamaian Kecamatan Stabat Kabupaten Langkat, dan tujuan penelitian ini adalah untuk mengetahui dan menganalisis pengaruh Pendidikan, Pelatihan dan Pengalaman mengajar guru terhadap Profesionalisme Guru di Sekolah Dasar ( SD ) Negeri 050662 Perdamaian Kecamatan Stabat Kabupaten Langkat. Penelitian ini merupakan penelitian deskriptif kuantitatif. Teknik pengumpulan data dilakukan melalui wawancara, daftar pertanyaan (questionaire) dan studi dokumentasi. Sampel dalam penelitian ini sebanyak 30 orang Guru di Sekolah Dasar ( SD ) Negeri 050662 Perdamaian Kecamatan Stabat Kabupaten Langkat. Variabel diukur dengan skala Likert. Pengujian hipotesis menggunakan analisis regresi linear berganda melalui uji $F$ dan uji t. Hasil uji secara serempak menunjukkan bahwa Pendidikan, Pelatihan dan Pengalaman Mengajar berpengaruh signifikan terhadap Profesionalisme Guru Sekolah Dasar (SD) Negeri 050662 Perdamaian Kecamatan Stabat dengan nilai koefisien determinasi sebesar 0,554 atau 55.4\%. Secara parsial, Pendidikan berpengaruh positif dan signifikan terhadap Profesionalisme Guru Sekolah Dasar (SD) Negeri 050662 Perdamaian Kecamatan Stabat dengan nilai koefisien regresi sebesar 0.330 atau 33.0\%. Pelatihan berpengaruh positif dan signifikan terhadap Profesionalisme Guru Sekolah Dasar (SD) Negeri 050662 Perdamaian Kecamatan Stabat dengan nilai koefisien regresi sebesar 0.355 atau 35.5\%. Pengalaman Mengajar berpengaruh positif dan signifikan terhadap Profesionalisme Guru Sekolah Dasar (SD) Negeri 050662 Perdamaian Kecamatan Stabat dengan nilai koefisien regresi
\end{abstract}


sebesar 0.365 atau 36.5\%. Nilai koefisien regresi yang paling tinggi adalah pengalaman mengajar sebesar 0.365 atau $36.5 \%$.

\section{Kata kunci : pendidikan, pelatihan, pengalaman mengajar, professional guru}

\section{Pendahuluan}

Profesional guru disyaratkan memenuhi kualifikasi akademik minimum dan bersertifikat sebagai pendidik. Hal tersebut sesuai dengan Undang-Undang Republik Indonesia Nomor 14 Tahun 2005 Tentang Guru dan Dosen BAB IV Pasal 8 dan 9, yaitu Bahwa guru wajib memiliki kualifikasi akademik, kompetensi, sertifikat pendidik, sehat jasmani dan rohani, serta memiliki kemampuan untuk mewujudkan tujuan pendidikan nasional. Kualifikasi akademik yaitu diperoleh melalui pendidikan tinggi program sarjana (S1) atau Program Diploma (DIV).

Standar kompetensi dan sertifikasi guru adalah untuk mendapatkan seorang guru yang baik dan profesional, yang memiliki kompetensi untuk melaksanakan fungsi dan tujuan sekolah khususnya, serta tujuan pendidikan pada umumnya sesuai dengan kebutuhan masyarakat dan tuntutan zaman. Dengan adanya seorang guru yang profesional baik dalam ijazah maupun dalam proses pembelajaran, maka tujuan pendidikan akan terwujud ( Sagala, $2014: 21$ ). Partisipan utama dalam interaksi pendidikan adalah guru dan para peserta didik yang saling berinteraksi dalam situasi pendidikan. Keberhasilan proses pendidikan banyak tergantung pada keefektifan prilaku individu yang terlibat di dalamnya yaitu perilaku guru, para peserta didik, situasi pendidikan, dan lingkungan pendidikan. Seorang guru yang baikadalah mereka yang memenuhi persyaratan kemampuan profesional baik sebagai pendidik maupun sebagai pengajar. Guru sebagai pengajar hendaknya mampu mewujudkan perilaku mengajar secara tepat agar mampu mewujudkan perilaku belajar peserta didik melalui interaksi belajar mengajar yang efektif dalam situasi yang kondusif (Surya, 2013: 261).

Guru bukanlah hanya berperan sebagai model atau teladan bagi peserta didik dalam proses belajar mengajar, akan tetapi juga sebagai pengelola pembelajaran. Keberhasilan suatu proses pembelajaran sangat ditentukan oleh kualitas atau kemampuan oleh seorang guru. Selain itu, seorang guru tidak hanya profesional dalam segi jenjang pendidikan, akan tetapi seorang guru diharuskan profesional dalam proses belajar mengajar. Menuju proses kegiatan belajar yang baik, tugas pokok seorang guru adalah mempersiapkan rancangan-rancangan pembelajaran yang sistematis dan berkelanjutan, seperti membuat RPP. Sehubungan dengan hal tersebut, seorang guru harus bersikap kreatif dan profesional ketika proses pembelajaran berlangsung. Membenahi profesionalitas seorang guru merupakan awal yang baik untuk meningkatkan mutu pendidikan di Negara ini. Dengan adanya para guru yang profesional, maka mutu pendidikan di Indonesia akan lebih maju daripada Negara-negara lainnya. Sebagai pendidik, guru merupakan salah satu faktor penentu keberhasilan setiap upaya dalam pendidikan khususnya dalam proses pembelajaran.

Pengalaman mengajar sebagai bagian dari pengalaman kerja yang harus dimiliki oleh seorang guru untuk dapat mengatasi permasalahan dalam tugasnya, karena harus disadari bahwa untuk menjadi guru yang profesional bukanlah hal yang mudah sebab hal tersebut menuntut banyak tanggung jawab. Dengan adanya pengalaman mengajar diharapkan mampu terus berkembang sesuai dengan perkembangan zaman, sebab guru senantiasa dituntut untuk menyesuaikan ilmu dan ketrampilannya dengan ilmu dan teknologi yang sedang berkembang. Pengalaman mengajar yang dimiliki oleh seorang guru tidak hanya berupa kegiatan pembelajaran di kelas saja tetapi juga kegiatan-kegiatan di luar proses belajar mengajar, yaitu penataran-penataran, seminar/lokakarya dan pelatihan-pelatihan, serta karya tulis yang pernah diikutinya. Melalui kegiatan-kegiatan tersebut guru dapat memperoleh pengetahuan baru, misalnya tentang pengembangan kurikulum, penggunaan metode dan media pembelajaran serta evaluasi hasil belajar. Semakin banyak pengalaman bermanfaat yang dimiliki seorang guru maka akan berpengaruh terhadap profesionalisme guru tersebut. Guru yang kaya akan pengalaman mengajar seharusnya lebih tanggap dalam menghadapi masalah yang berhubungan dengan proses belajar mengajar, karena pengalaman-pengalaman bermanfaat yang dimilikinya dapat dijadikan sebagai bahan acuan selama ia menjalankan tugasnya sebagai guru. 


\subsection{Rumusan Masalah}

Berdasarkan latar belakang masalah tersebut diatas, maka yang menjadi rumusan masalah dalam penelitian ini adalah, bagaimana pengaruh Pendidikan, Pelatihan dan Pengalaman mengajar guru terhadap Profesionalisme Guru di Sekolah Dasar ( SD ) Negeri 050662 Perdamaian Kecamatan Stabat Kabupaten Langkat.

\subsection{Batasan Masalah}

Batasan masalah dalam penelitian ini adalah membatasi variabel Pendidikan, Pelatihan dan Pengalaman Mengajar guru yang secara parsial dan simultan yang memberikan kontribusi ataupun tidak terhadap peningkatan Profesionalisme Guru terkhusus di Sekolah Dasar ( SD ) Negeri 050662 Perdamaian Kecamatan Stabat Kabupaten Langkat.

\subsection{Hipotesis}

Dari rumusan masalah, batasan masalah dan uraian teoritis yang dijelaskan di atas, maka dugaan sementara atau hipotesi yang diambil tentang variable yang diteliti, adalah sebagai berikut : Pendidikan, pelatihan dan pengalaman mengajar berpengaruh secara simultan terhadap terhadap profesionalisme guru di Sekolah Dasar ( SD ) Negeri 050662 Perdamaian Kecamatan Stabat Kabupaten Langkat.

\subsection{Tujuan Penelitian}

Berdasarkan rumusan masalah penelitian sebagaimana diuraikan di atas, maka tujuan yang hendak dicapai dalam penelitian ini yaitu:

a. Untuk mengetahui pengaruh antara Pendidikan terhadap Profesionalisme Guru di Sekolah Dasar ( SD ) Negeri 050662 Perdamaian Kecamatan Stabat Kabupaten Langkat.

b. Untuk mengetahui pengaruh antara Pelatihan terhadap Profesionalisme Guru di Sekolah
Dasar ( SD ) Negeri 050662 Perdamaian Kecamatan Stabat Kabupaten Langkat.

c. Untuk mengetahui pengaruh antara Pengalaman mengajar guru terhadap Profesionalisme Guru di Sekolah Dasar ( SD ) Negeri 050662 Perdamaian Kecamatan Stabat Kabupaten Langkat.

d. Untuk mengetahui secara simultan antara hubungan Pendidikan, Pelatihan dan Pengalaman mengajar guru terhadap Profesionalisme Guru di Sekolah Dasar ( SD ) Negeri 050662 Perdamaian Kecamatan Stabat Kabupaten Langkat.

\section{Metode Penelitian \\ 2.1.Populasi dan Sampel}

Populasi dalam penelitian ini adalah seluruh guru di SD Negeri 050662 Perdamaian Kecamatan Stabat Kabupaten Langkat sebanyak 31 orang.

Tabel 1. Kerangka Populasi Berdasarkan Jabatan Fungsional Thn. 2019

\begin{tabular}{|c|c|c|}
\hline No & Jabatan & $\begin{array}{c}\text { Jlh } \\
\text { Populasi }\end{array}$ \\
\hline 1 & $\begin{array}{l}\text { Kepala } \\
\text { Sekolah }\end{array}$ & 1 \\
\hline 2 & Tata Usaha & 2 \\
\hline 3 & Pustakawan & 1 \\
\hline 4 & Guru Kelas & 14 \\
\hline 5 & Guru & 6 \\
\hline 6 & Guru Honorer & 6 \\
\hline & Jumlah & 31 \\
\hline
\end{tabular}

Dengan teknik penarikan sampel secara Total Sampling maka sampel dalam penelitian ini adalah seluruh populasi yaitu 30 orang guru di SD Negeri 050662 Perdamaian Kecamatan. Sampel ini tidak termasuk Kepala Sekolah SD Negeri 050662 Perdamaian Kecamatan Kabupaten Langkat.

Tabel 2. Kerangka Sampel Berdasarkan Jabatan Fungsional Thn. 2019

\begin{tabular}{|c|l|c|c|c|}
\hline No & \multicolumn{1}{|c|}{ Jabatan } & $\begin{array}{c}\text { Jlh } \\
\text { Populasi }\end{array}$ & $\begin{array}{c}\text { Jlh } \\
\text { Sampel }\end{array}$ & Keterangan \\
\hline 1 & Kepala Sekolah & 1 & - & $\begin{array}{c}\text { Tidak } \\
\text { Diteliti }\end{array}$ \\
\hline 2 & Tata Usaha & 2 & 2 & Diteliti \\
\hline 3 & Pustakawan & 1 & 1 & Diteliti \\
\hline 4 & Guru Kelas & 14 & 14 & Diteliti \\
\hline 5 & Guru & 6 & 6 & Diteliti \\
\hline 6 & Guru Honorer & 6 & 6 & Diteliti \\
\hline \multicolumn{2}{|r|}{ Jumlah } & $\mathbf{3 1}$ & $\mathbf{3 0}$ & \\
\hline
\end{tabular}

Sumber: SD Negeri 050662 Perdamaian Kecamatan Stabat. 


\subsection{Uji Normalitas Data}

Uji normalitas untuk mengetahui apakah ada model regresi, variabel independed dan variabel dependen mempunyai distribusi normal. Untuk menguji normalitas penulis menggunakan analisis gambar yaitu dengan melihat pada gambar histogram yang memiliki bentuk seperti lonceng. Dan gambar grafik dimana sebaran titiktitik mendekati atau berada digaris diagonal. Hasil pengujian normalitas dapat dilihat dam gambar sebagai berikut:

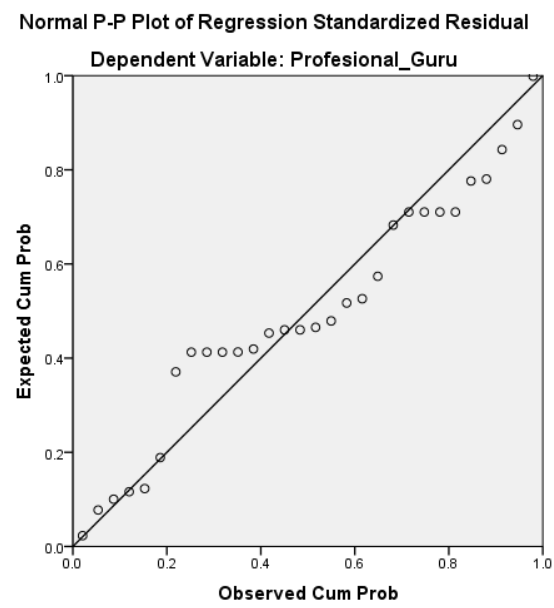

Gambar 1. Hasil Pengujian Normalitas-Diagonal

Berdasarkan hasil pengujian normalitas diagonal gambar 1, diatas terlihat jelas bahwa distribusi dari titik-titik data Pendidikan, Pelatihan, Pengalaman Mengajar dan Profesionalisme menyebar. Grafik P-P Plot diatas menunjukan bahwa sebaran data menyebar disekitar garis diagonal, sehingga asumsi normalitas dipenuhi. Maka model regresi layak dipakai untuk memprediksi Profesionalisme berdasarkan variabel independennya

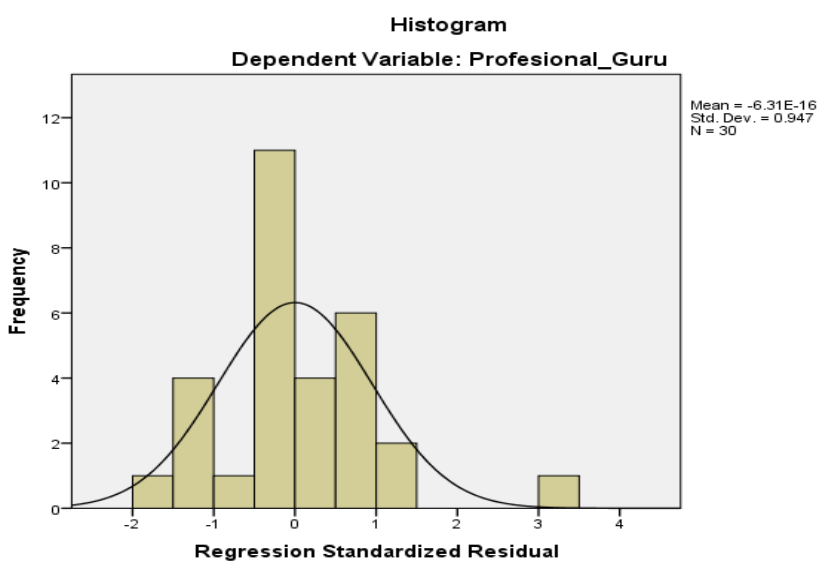

Gambar 2. Hasil Pengujian Normalitas-

Histogram

Berdasarkan hasil pengujian normalitas pada gambar 2. diatas, terlihat jelas bahwa gambar histogram memiliki bentuk seperti lonceng, tegak, condong ke kiri dan ke kanan.

\subsection{Uji Multikolinearitas}

Multikolinieritas berati adanya hubungan yang kuat diantara beberapa atau semua variabel bebas pada model regresi. Jika terdapat multikolinieritas maka koefisien regresi menjadi tidak tentu, tingkat kesalahannya menjadi sangat besar dan biasanya ditandai dengan koefisien determinasi yang sangat besar tetapi pada pengujian parsial koefisien regresi, tidak ada atau pun kalau ada sangat sedikit sekali koefisien regresi yang signifikan. Pada penelitian ini digunakan nilai Variance Inflantion Factorrs (VIF) sebagai indikator ada tidaknya multikolinearitas di antara variabel bebas.

Tabel 3. Uji Multikolinieritas Coefficients $^{\mathrm{a}}$

\begin{tabular}{|ll|r|r|r|}
\hline \multirow{2}{*}{ Model } & \multicolumn{1}{|c|}{ Correlations } & \multicolumn{2}{|c|}{ Collinearity Statistics } \\
\cline { 2 - 4 } \multicolumn{1}{|c|}{ (Constant) } & Part & Tolerance & \multicolumn{1}{c|}{ VIF } \\
\hline \multirow{2}{*}{1} & & & \\
& Pendidikan & .287 & .757 & 1.321 \\
& Pelatihan & .318 & .804 & 1.244 \\
& Pengalaman_Mengajar & .352 & .934 & 1.071 \\
\hline
\end{tabular}

a. Dependent Variable: Profesional_Guru

Berdasarkan pengolahan data pada tabel 3, dapat dilihat hasil perhitungan nilai Tolarance dan VIF masing-masing pendidikan sebesar 1,321(lebih besar dari 0,1) dan pelatihan sebesar 1,244 lebih besar dari 10) dan pengalaman mengajar sebesar 1,071 (lebih besar dari 0,1 ) sehingga dapat disimpulkan bahwa model regresi ini terbebas dari multikolinieritas. 


\subsection{Uji Heteroskedastisitas}

Uji Heteroskedasitas digunakan untuk melihat apakah dalam model regresi terjadi ketidaksamaan variance dari residual satu pengamatan kepengamatan yang lain.

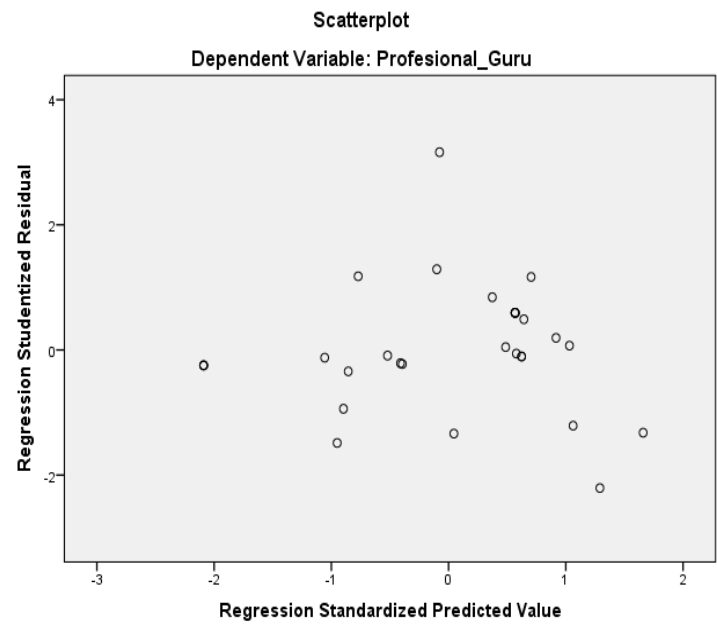

Gambar 3 Grafik scatterplot Uji Heteroskedastisitas
Penguji asumsi heteroskedasitas menyimpulkan bahwa model regresi tidak terjadi heteroskedasitas. Dengan kata lain terjadi kesamaan varian dari residual dari satu pengamatan ke pengamatan yang lain. Kesimpulan ini diperoleh dengan melihat penyebaran titi-titik yang menyebar secara acak, tidak membentuk sebuah pola tertentu yang jelas, serta tersebar baik diatas maupun dibawah dengan angka 0 pada sumbu $Y$.

\section{Hasil dan Pembahasan}

\subsection{Analisis Regresi Linier Berganda}

Penulis mengolah data-data yang ada dengan menggunakan program spss versi 22 dengan Data Melalui Program Tersebut Penulis Memperoleh Persamaan Regresi Linier Berganda, Besarnya Pengaruh Pendidikan, Pelatihan Dan Pengalaman Mengajar Terhadap Profesionalisme Guru Di Sekolah Dasar ( Sd ) Negeri 050662 Perdamaian Kecamatan Stabat Kabupaten Langkat

Tabel 4. Regresi Linear Berganda

Coefficients $^{a}$

\begin{tabular}{|c|c|c|c|c|c|}
\hline \multirow[t]{2}{*}{ Model } & \multicolumn{2}{|c|}{$\begin{array}{c}\text { Unstandardized } \\
\text { Coefficients }\end{array}$} & $\begin{array}{l}\text { Standardized } \\
\text { Coefficients }\end{array}$ & \multirow[t]{2}{*}{$\mathrm{t}$} & \multirow[t]{2}{*}{ Sig. } \\
\hline & $\mathrm{B}$ & $\begin{array}{c}\text { Std. } \\
\text { Error }\end{array}$ & Beta & & \\
\hline (Constant) & 10.836 & 3.354 & & 3.231 & .003 \\
\hline Pendidikan & .324 & .148 & .330 & 2.189 & .038 \\
\hline Pelatihan & .296 & .122 & .355 & 2.429 & .022 \\
\hline Pengalaman_Mengajar & .195 & .073 & .365 & 2.690 & .012 \\
\hline
\end{tabular}

Tabel diatas menggambarkan persamaan analisis regresi berganda sebagaimana yang telah penulis uraikan sebelumnya,yaitu:

$$
y=a+b_{1} x_{1}+b_{2} x_{2}+b_{3} x_{3}+\varepsilon
$$

$$
Y=10.836+0.324 X_{1}+0.296 X_{2}+0.195 X_{3}+\varepsilon
$$

Dengan persamaan regresi linier berganda tersebut dapat dijelaskan bahwa :

a. Nilai konstanta adalah sebesar $\mathbf{1 0 . 8 3 6}$ hal ini menyatakan bahwa jika variable Pendidikan, Pelatihan dan Pengalaman Mengajar diabaikan, maka nilai Profesionalisme sebesar 10.836 .

b. Koefisien regresi untuk variabel Pendidikan sebesar 0.324 hal ini menunjukkan bahwa setiap kenaikan $1 \%$ faktor Pendidikan maka akan meningkatkan Profesionalisme Guru sebesar $32.4 \%$.

c. Koefisien regresi untuk variabel Pelatihan sebesar 0.296 hal ini menunjukkan bahwa setiap kenaikan $1 \%$ faktor Pelatihan maka akan meningkatkan Profesionalisme Guru sebesar $29.6 \%$.

d. Koefisien regresi untuk variabel Pengalaman Mengajar sebesar 0,195 hal ini menunjukkan bahwa setiap kenaikan $1 \%$ faktor Pengalaman Mengajar maka akan meningkatkan Profesionalisme Guru sebesar $19.5 \%$.

\subsection{Hipotesis}

3.2.1. Uji Simultan ( Uji- f ) 
Tabel 5. Hasil Uji Serempak ANOVA $^{\mathrm{a}}$

\begin{tabular}{|c|c|c|c|c|c|c|}
\hline \multicolumn{2}{|c|}{ Model } & $\begin{array}{l}\text { Sum of } \\
\text { Squares }\end{array}$ & $\mathrm{df}$ & Mean Square & $\mathrm{F}$ & Sig. \\
\hline \multirow{3}{*}{1} & Regression & 90.740 & 3 & 30.247 & 10.754 & $.000^{\mathrm{b}}$ \\
\hline & Residual & 73.127 & 26 & 2.813 & & \\
\hline & Total & 163.867 & 29 & & & \\
\hline
\end{tabular}

b. Predictors: (Constant), Pengalaman_Mengajar, Pelatihan, Pendidikan

Pada Tabel 5 di atas terlihat nilai signifikansi sebesar $0.000^{\mathrm{b}}$ lebih kecil dari $\alpha=0,05$, hal ini berarti bahwa variabel Pendidikan dan Pelatihan serta Pengalaman Mengajar sebagai variabel bebas memiliki pengaruh yang highly significant.

\subsubsection{Uji Parsial ( Uji- t )}

Tabel 6. Hasil Uji Parsial

Coefficients $^{\mathrm{a}}$

\begin{tabular}{|c|c|c|c|c|c|c|}
\hline \multirow{2}{*}{\multicolumn{2}{|c|}{ Model }} & \multicolumn{2}{|c|}{$\begin{array}{c}\text { Unstandardized } \\
\text { Coefficients }\end{array}$} & $\begin{array}{c}\text { Standardized } \\
\text { Coefficients }\end{array}$ & \multirow[t]{2}{*}{$\mathrm{t}$} & \multirow[t]{2}{*}{ Sig. } \\
\hline & & B & $\begin{array}{l}\text { Std. } \\
\text { Error }\end{array}$ & Beta & & \\
\hline \multirow{4}{*}{1} & (Constant) & 10.836 & 3.354 & & 3.231 & .003 \\
\hline & Pendidikan & .324 & .148 & .330 & 2.189 & .038 \\
\hline & Pelatihan & .296 & .122 & .355 & 2.429 & .022 \\
\hline & Pengalaman_Mengajar & .195 & .073 & .365 & 2.690 & .012 \\
\hline
\end{tabular}

Dari Tabel 6 , diperoleh nilai $t_{\text {hitung }}$ masingmasing variabel. Nilai $t_{\text {hitung }}$ tersebut selanjutnya dibandingkan dengan nilai $t_{\text {tabel }}$ pada tingkat kepercayaan $95 \%$ atau $\alpha=0,05$. Nilai $t_{\text {tabel }}$ pada df 3:30 dengan $\alpha=0,05$ adalah 2.042. Pengaruh parsial dari variabel Pendidikan $\left(\mathrm{X}_{1}\right)$ diperoleh dengan nilai $t_{\text {hitung }}$ sebesar 2.189, dengan demikian $t_{\text {hitung }}>t_{\text {tabel }}(2.189>2.042)$ dengan nilai signifikan sebesar $0.038<0.05$, maka $\mathrm{H}_{0}$ ditolak dan $\mathrm{H}_{1}$ diterima, yang berarti bahwa variabel Pendidikan $\left(\mathrm{X}_{1}\right)$ berpengaruh positif dan signifikan terhadap Profesionalisme Guru Sekolah Dasar (SD) Negeri 050662 Perdamaian Kecamatan Stabat . Hal ini berarti bahwa apabila Pendidikan $\left(\mathrm{X}_{1}\right)$ meningkat atau semakin baik maka Profesionalisme Guru Sekolah Dasar (SD) Negeri 050662 Perdamaian Kecamatan Stabat juga akan meningkat.

Pengaruh parsial dari variabel Pelatihan $\left(\mathrm{X}_{2}\right)$ diperoleh dengan nilai $t_{\text {hitung }}$ sebesar 2.429, dengan demikian $t_{\text {hitung }}>t_{\text {tabel }}(2.429>2.042)$ dengan nilai signifikan sebesar $0.022<0.05$, maka $\mathrm{H}_{0}$ ditolak dan $\mathrm{H}_{1}$ diterima, yang berarti bahwa variabel Pelatihan $\left(\mathrm{X}_{2}\right)$ berpengaruh positif dan signifikan terhadap Profesionalisme
Secara serempak variabel Pendidikan dan Pelatihan serta Pengalaman Mengajar menunjukkan pengaruh sangat nyata terhadap Profesionalisme Guru Sekolah Dasar (SD) Negeri 050662 Perdamaian Kecamatan Stabat .
Guru Sekolah Dasar (SD) Negeri 050662 Perdamaian Kecamatan Stabat. Hal ini berarti bahwa apabila Pelatihan $\left(\mathrm{X}_{2}\right)$ meningkat atau semakin baik maka Profesionalisme Guru Sekolah Dasar (SD) Negeri 050662 Perdamaian Kecamatan Stabat juga akan meningkat.

Pengaruh parsial dari variabel Pengalaman Mengajar $\left(X_{3}\right)$ diperoleh dengan nilai $t_{\text {hitung }}$ sebesar 2.690, dengan demikian $t_{\text {hitung }}>t_{\text {tabel }}$ $(2.690>2.042)$ dengan nilai signifikan sebesar $0.012<0.05$, maka $\mathrm{H}_{0}$ ditolak dan $\mathrm{H}_{1}$ diterima, yang berarti bahwa variabel Pengalaman Mengajar $\left(\mathrm{X}_{3}\right)$ berpengaruh positif dan signifikan terhadap Profesionalisme Guru Sekolah Dasar (SD) Negeri 050662 Perdamaian Kecamatan Stabat. Hal ini berarti bahwa apabila Pengalaman Mengajar $\left(\mathrm{X}_{3}\right)$ meningkat atau semakin baik maka Profesionalisme Guru Sekolah Dasar (SD) Negeri 050662 Perdamaian Kecamatan Stabat juga akan meningkat.

Berdasarkan hasil analisis diketahui bahwa nilai koefisien regresi yang paling tinggi adalah variabel Pengalaman Mengajar $\left(\mathrm{X}_{3}\right)$ sebesar 0.365 atau $36.5 \%$. Hal ini berarti bahwa Pengalaman Mengajar $\left(\mathrm{X}_{3}\right)$ berpengaruh lebih dominan terhadap Profesionalisme Guru Sekolah 
Dasar (SD) Negeri 050662 Perdamaian 3.2.3. Uji Determinasi $\boldsymbol{R}^{\mathbf{2}}$

Kecamatan Stabat .

Tabel 7. Koefisien Determinasi

Model Summary ${ }^{b}$

\begin{tabular}{|c|c|c|c|c|c|c|}
\hline \multirow[t]{2}{*}{ Model } & \multirow[t]{2}{*}{$\mathrm{R}$} & \multirow[t]{2}{*}{ R Square } & \multirow{2}{*}{$\begin{array}{l}\text { Adjusted R } \\
\text { Square }\end{array}$} & \multirow{2}{*}{$\begin{array}{l}\text { Std. Error of } \\
\text { the Estimate }\end{array}$} & \multicolumn{2}{|c|}{ Change Statistics } \\
\hline & & & & & $\begin{array}{l}\text { R Square } \\
\text { Change }\end{array}$ & F Change \\
\hline 1 & $.744^{\mathrm{a}}$ & .554 & .502 & 1.677 & .554 & 10.754 \\
\hline
\end{tabular}

a. Predictors: (Constant), Pengalaman_Mengajar, Pelatihan, Pendidikan

b. Dependent Variable: Profesional_Guru

Nilai koefisien determinasi sebesar 0,554 berarti bahwa terhadap Profesionalisme Guru Sekolah Dasar (SD) Negeri 050662 Perdamaian Kecamatan Stabat dapat dijelaskan oleh perubahan Pendidikan dan Pelatihan serta Pengalaman Mengajar sebesar 55.4\%, sedangkan sisanya sebesar $44.6 \%$ dipengaruhi oleh variable lain yang tidak dianalisis dalam penelitian ini.

\section{Kesimpulan}

Berdasarkan uraian dan penjelasan dari babbab yang terdahulu, maka penulis mengambil kesimpulan sebagai berikut:

a. Pendidikan berpengaruh positif dan signifikan terhadap Profesionalisme Guru Sekolah Dasar (SD) Negeri 050662 Perdamaian Kecamatan Stabat dengan nilai koefisien regresi sebesar 0.330 atau $33.0 \%$.

b. Pelatihan berpengaruh positif dan signifikan terhadap Profesionalisme Guru Sekolah Dasar (SD) Negeri 050662 Perdamaian Kecamatan Stabat dengan nilai koefisien regresi sebesar 0.355 atau $35.5 \%$.

c. Pengalaman Mengajar berpengaruh positif dan signifikan terhadap Profesionalisme Guru Sekolah Dasar (SD) Negeri 050662 Perdamaian Kecamatan Stabat dengan nilai koefisien regresi sebesar 0.365 atau $36.5 \%$.

d. Pendidikan, Pelatihan dan Pengalaman Mengajar berpengaruh signifikan terhadap Profesionalisme Guru Sekolah Dasar (SD) Negeri 050662 Perdamaian Kecamatan Stabat dengan nilai koefisien determinasi sebesar 0,554 atau $55.4 \%$.

\section{DAFTAR PUSTAKA}

Agustinari, Titiek. 2012. Pengaruh Motivasi Mengajar dan Pengalaman Mengajar terhadap Profesionalisme Guru SMP Negeri di Kecamatan Jetis Kota Yogyakarta.

Ahmadi, Abu dan Nur Uhbiyati. 2014. Ilmu Pendidikan. Jakarta : PT. Rineka Cipta.
Ahmadi, Abu. 2014. Psikologi Pendidikan. Jakarta : PT. Rineka Cipta.

Amstrong, Michael. 2010. Manajemen Sumber Daya Manusia. Jakarta : PT. Elex Media Komputindo.

Artasasmita, Romli. 2013. Teori dan praktek Manajemen Pendidikan. Yogyakarta : UII Pers.

Azwar, Saifuddin. 2011. Metode Penelitian. Yogyakarta : Pustaka Pelajar.

Handoko, T Hani. 2010. Menejemen Personalia dan Sumber Daya Manusia. Yogyakarta : BPFE.

Haris, Herdiansyah. 2010. Metode Penelitian Kualitatif Untuk Ilmu - Ilmu Sosial. Jakarta : Salemba Humanika.

Kamil, Mustofa. 2010. Model Pendidikan dan Pelatihan (Konsep dan Aplikasi). Bandung : Alfabeta.

Kamil, Mustofa. 2010. Strategi dan Model Pembelajaran. Bandung : Alfabeta.

Kaplan, R.M. dan Saccuzzo, D.P. 2013. Psychological Testing Principles, Application and Issues, Sixth Edition. USA : Wadsworth.

Kasnawati. 2015. Pengaruh Guru Propesional, Pendidikan dan Pelatihan Terhadap Kinerja Guru di SMPN 1 Bontoramba Kabupaten Jeneponto.

Kunandar, 2011, Guru Profesional: Impelentasi Kurikulum Tingkat Satuan Pendidikan (KTSP) dan Sukses Dalam Sertfikasi Guru, (Jakarta: Rajawali Pers,) hlm. 45.

-------. 2015. Pembelajaran Yang Efektif dan Menyenangkan. Jakarta : PT. Raja Grafindo persada.

Mangkunegara, Anwar Prabu. 2010. Manajemen Sumber Daya Manusia. Bandung : PT. Remaja Rosdakarya.

Marzuki. 2012. Pengintegrasian pendidikan Karakter Dalam Pembelajaran di Sekolah. Yogyakarta : FIS-UNY

Moekizat. 2012. Teori Komunikasi. Bandung. Mandar Maju. 
Mohamad Surya, 2013, Percikan Perjuangan Guru, (Semarang: Aneka Ilmu) hlm. 261

Mulyasa, E. 2011. Manajemen Berbasis Sekolah. Bandung : PT. Remaja Rosda Karya.

Muslich, Masnur. 2012. Pendidikan Karakter Menjawab Tantangan Krisis Multidimensional. Jakarta : Bumi Aksara.

Nginun Naim, 2012, Menjadi Guru Inspiratif, (Yogyakarta: Pustaka Pelajar) hlm. 11

Notoadmodjo, Soekidjo. 2013. Pengembangan Sumber Daya Manusia. Jakarta : Rineka Cipta.

Nurjannah. 2015. Manajemen Bencana. Bandung : Alfabeta.

Permendiknas Nomor 18 Tahun 2007 Tentang Sertifikasi Bagi Guru Dalam Jabatan.

Sadeli, Muhammad. 2013. Tujuh Jam Belajar Interaktif. Pelmbang : Maxicom.

Samsudin, Sadili. 2013. Manajemen Sumber Daya Manusia. Bandung : Pustaka Setia.

Sastroadipoera, Komarudin. 2016. Strategi Pengembangan Sumber Daya Berbasis Pendidikan Kebudayaan. Bandung : Kappa Sigma.

Sastrohadiwiryo, B.S. 2015. Manajemen Tenaga Kerja Indonesia Pendekatan Administratif dan Operasional. Jakarta : PT. Bumi Aksara.

Soediyarto. 2013. Landasan dan Arah Pendidikan Nasional Kita. Jakarta : Kompas.

Sudjana, Nana. 2010. Panduan Aplikasi Teori Teori Belajar Mengajar. Bandung : PT. Remaja Rosdakarya.

Sugito. 2011. Manajemen Pendidikan Teori dan Praktek. Jakarta : Rineka Cipta.

Sugiyono. 2010. Memahami Penelitian Kualitatif. Bandung : Alfabeta.

Sugiyono. 2017. Metode Penelitian Administrasi. Bandung : Alfabeta.

Suharyadi. 2014. Metode Penelitian Pendidikan. Jakarta : Salemba Empat.

Sukadi, D K. 2016. Bimbingan dan Konseling. Bandung : Bina Aksara.

Sulistiyani, Ambar Teguh dan Rosidah. 2013. Manajemen Sumber Daya Manusia. Yogyakarta : Graha Ilmu.

Sumodiningrat, Gunawan. 2011. Menejemen Pendidikan. Yogyakarta : Pustaka Pelajar.

Suprijanto. 2015. Pendidikan Orang Dewasa. Jakarta : Bumi Aksara.

Syamsul Ma'arif, 2011, Guru Profesional: Harapan dan Kenyataan, (Semarang: Need's Press) hlm. 8-9.
Syaiful Sagala, 2014, Kemampuan Profesional Guru dan Tenaga Kependidikan, (Bandung: Alfabeta) hlm. 21 .

Tilaar, H. A. R. 2011. Pendidikan Kebudayaan dan Masyarakat Madani Indonesia. Bandung : Remaja Rosdakarya.

Thoifuri, 2012, Menjadi Guru Inisiator, (Semarang: Rasail Media Group) hlm. 33.

Undang - Undang Republik Indonesia Nomor 14 Tahun 2005 Tentang Guru dan Dosen. Jakarta : Dharma Bakti.

Walgito, Bimo. 2013. Pengantar Psikologi Umum. Yogyakarta : ANDI.

Zen, Muhammad. 2010. Manajemen Perpajakan. Jakarta : Salemba Empat. 